\title{
A 3D Modelling of Solar Cell's Electric Power under Real Operating Point
}

\author{
Mayoro Dieye1, Senghane Mbodji², Martial Zoungrana33, Issa Zerbo3, Biram Dieng2, \\ Gregoire Sissoko ${ }^{1}$ \\ ${ }^{1}$ Laboratory of Semiconductors and Solar Energy, Department of Physics, Faculty of Science and Technology, \\ Cheikh Anta Diop University, Dakar, Senegal \\ ${ }^{2}$ Department of Physics, Alioune DIOP University of Bambey, Bambey, Senegal \\ ${ }^{3}$ Laboratoire d'Energies Thermiques et Renouvelables (L.E.T.RE), Departement de Physique, U.F.R-S.E.A, \\ Universitede Ouagadougou, Ouagadougou, Burkina Faso \\ Email: gsissoko@yahoo.com
}

Received 19 October 2015; accepted 14 November 2015; published 17 November 2015

Copyright (C) 2015 by authors and Scientific Research Publishing Inc.

This work is licensed under the Creative Commons Attribution International License (CC BY).

http://creativecommons.org/licenses/by/4.0/

(c) † Open Access

\section{Abstract}

This work, based on the junction recombination velocity $\left(S f_{u}\right)$ concept, is used to study the solar cell's electric power at any real operating point. Using $S f_{u}$ and the back side recombination velocity $\left(S b_{u}\right)$ in a 3D modelling study, the continuity equation is resolved. We determined the photocurrent density, the photovoltage and the solar cell's electric power which is a calibrated function of the junction recombination velocity $\left(S f_{u}\right)$. Plots of solar cell's electric power with the junction recombination velocity give the maximum solar cell's electric power, $P_{m}$. Influence of various parameters such as grain size $(g)$, grain boundaries recombination velocity $(S g b)$, wavelength $(\lambda)$ and for different illumination modes on the solar cell's electric power is studied.

\section{Keywords}

Electric Power, Grain Size, Grain Boundary Recombination Velocity, Polycrystalline, Solar Cell, Junction Recombination Velocity

\section{Introduction}

Our work is grounded on the junction recombination velocity $\left(S f_{u}\right)[1]$ and the back side recombination velocity $\left(S b_{u}\right)$ [2] of the solar cell; subscript $u$ refers to the illumination mode. With the junction recombination velocity concept, introduced in 1996 [1], modelling and characterization of solar cells were made possible for any operating point of the solar cell from the open circuit to short-circuit real operating points. The junction recombina- 
tion velocity is related to external load, to their time of use and the season, the month and day of use.

Thus, one-dimensional (1D) studies which used the steady and transient states of the solar cell have determined with great precision, the lifetime of excess minority carriers, their diffusion length, the effective recombination velocity at the backside of the solar cell, the intrinsic junction recombination velocity $\left(S f_{0, u}\right)$, the characteristic I-V and shunt and series resistances [3] [4]. For studying the influence of electromagnetic waves produced by an amplitude modulation radio antenna on the electric power delivered by a silicon solar cell, a 1D study is used by [5]. In these works [3]-[5], authors proved that the intensity of the electromagnetic field depended on the distance between the solar cell and the amplitude modulation radio antenna. Taking into account the wavelength of the monochromatic radiation, they [5] also determined the maximum electric power and the corresponding operating point of the solar cell according to distance or electromagnetic field intensity.

However for polycrystalline silicon solar cells that provide the best efficiencies [6] but are made by small grains with various geometrical shape, it is necessary to make a 3D study to clearly identify the effect of grain size $(g)$ and grain boundaries recombination velocity $(S g b)$. The solar cell's extension region width of the junction which could be considered as a plane capacitor with two identical plane electrodes separated by a thickness $(d)$ is a function of these two parameters [7]. For high grain boundary recombination velocity ( $\mathrm{Sg} b)$, the thickness obtained under open-circuit condition reaches to those obtained in short-circuit condition and the electron doesn't cross the junction [7]. But for high grain size, there is an important gap between thicknesses obtained respectively under open-circuit and short-circuit conditions and corresponding to the best solar cell [7].

The efficiency of the solar cell is calculated as the ratio between the maximum power, $P_{m}$, generated by the solar cell and the power of the incident light's flux, $P_{i n}$; subscript $m$ refers here to the maximum power point in the module's I-V curve [8].

Calculation of the solar cell's maximum electric power is then fundamental for photovoltaic devices characterization. That is why, the maximum powerpoint tracking (MPPT) control [9] [10] is developed and its role is to follow the maximum power point (MPP) of the photovoltaic module [11].

In this paper, we used the junction recombination velocity $\left(S f_{u}\right)$ to determine the generated power of the solar for any operating point. Within the first section, the basic theory is presented while the junction recombination velocity's role and the results related to the influence of grain size $(g)$, grain boundary recombination velocity $(S g b)$, the wavelength $(\lambda)$ and the illumination modes are presented in the second part of this paper.

\section{Theoretical Analysis}

A bifacial solar cell is a device which generates electricity directly from visible light. When light quanta are absorbed, electron hole pairs are generated as it can be seen in Figure 1(a).

An $\mathrm{n}^{+} \mathrm{p}^{-\mathrm{p}^{+}}$poly crystalline solar cell, made of many small individual grains, is considered.

Taking into account of the physical process simulation, the 2D representation of the solar cell is illustrated in Figure 1(a) and in Figure 1(b), the fibrously oriented columnar grain is considered.

The following three illumination modes are considered: front illumination, rear side illumination and simultaneous front and back side illumination. Hence, the electron-hole pairs generation rate $G_{u}(z)$, related to each illumination mode is expressed as [12]:

$$
G_{u}(z)=\alpha(\lambda) \cdot I_{0} \cdot(1-R(\lambda)) \cdot(\varepsilon \cdot \exp (-\alpha \cdot z)+\gamma \cdot \exp (-\alpha \cdot(H-z)))
$$

Table 1 illustrates the values of $\varepsilon$ and $\gamma$.

Coefficient $\alpha(\lambda)$ denotes the absorption of the monochromatic illumination [13]. $I_{0}$ is the incident photon flux and $R(\lambda)$ is the reflection at the wavelength, $\lambda[13]$.

At the junction, $\mathrm{N}^{+}$-P interface $\left.(\mathrm{z}=0)\right), S f_{u}$ quantifies how the excess carriers flow through the junction in actual operating conditions and then $S f_{u}$ characterizes how electrons cross to the junction [1] [3]-[5].

At the back side of the solar cell, $\left(S b_{u}\right)$ is used to translate the losses in this zone. It quantifies hence, the rate at which excess minority carriers are lost at the back side of the cell [1]-[7].

\subsection{Excess Minority Carriers Density}

The solar cell's emitter is considered as a dead zone. So, the excess minority carriers density is determined taking account into only the contribution of the solar cell's base. 


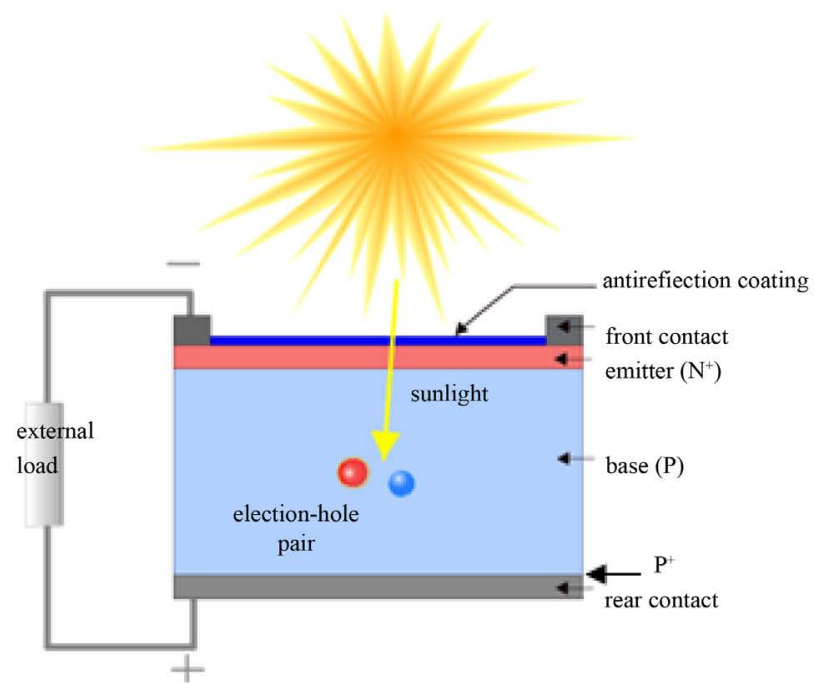

(a)

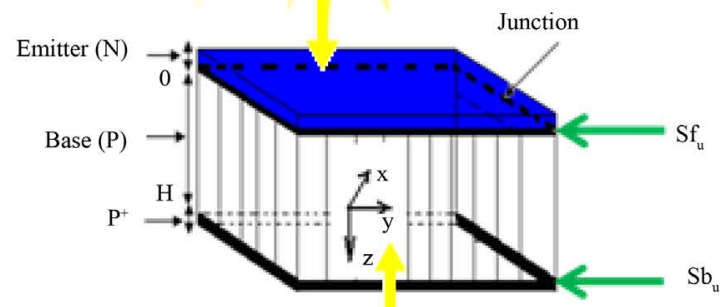

(b)

Figure 1. (a) 2D representation of the monofacialsolar cell [11]; (b) 3D representation of the solar cell $H=130 \mu \mathrm{m}, D=26$ $\mathrm{cm}^{2} \cdot \mathrm{s}^{-1}$.

Table 1. Range of $\varepsilon$ and $\gamma$.

\begin{tabular}{ccc} 
Illumination mode & $\varepsilon$ & $\gamma$ \\
\hline Front side illumination $(u=f r)$ & 1 & 0 \\
Rear side illumination $(u=r)$ & 0 & 1 \\
Simultaneous illumination $(u=s)$ & 1 & 1 \\
\hline
\end{tabular}


The excess minority carriers density is derived from the continuity equation [7]:

$$
D \cdot\left(\frac{\partial^{2} \delta_{u}(x, y, z)}{\partial^{2} x}+\frac{\partial^{2} \delta_{u}(x, y, z)}{\partial^{2} y}+\frac{\partial^{2} \delta_{u}(x, y, z)}{\partial^{2} z}\right)-\frac{\delta_{u}(x, y, z)}{\tau}=-G_{u}(z)
$$

where $D$ is excess minority carriers diffusion constant while $\tau$ is the lifetime of the excess minority carriers in the base of the solar cell.

The general solution of this equation is:

$$
\delta_{u}(x, y, z)=\sum_{k}^{\infty} \sum_{j}^{\infty} Z_{k j}(z) \cdot \cos \left(x \cdot c_{k}\right) \cdot \cos \left(y \cdot c_{j}\right) .
$$

The factors $c_{k}$ and $c_{j}$ are eigen values and depend on grain size $(g)$ and grain boundary recombination velocity (Sgb) only. Parameter $Z_{k j}(z)$ express the z-dependence of $\delta_{u}(x, y, z)$. $k$ and $j$ vary form 1 to 30 .

Inserting the Equation (3) into (2) and replacing the expression of generation by its value and taking into account of the fact that $\cos \left(c_{k} x\right)$ and $\cos \left(c_{j} x\right)$ are orthogonal functions, we obtain:

$$
Z_{k j, u}^{\prime \prime}(z)-\frac{Z_{k j, u}(z)}{L_{k j}^{2}}=-\frac{16 \sin \left(\frac{g \cdot c_{k}}{2}\right) \cdot \sin \left(\frac{g \cdot c_{j}}{2}\right)}{D \cdot c_{k} \cdot c_{j} \cdot F_{k j}} \cdot G_{u}(z)
$$

where $L_{k j}=\left(\frac{1}{L^{2}}+c_{k}^{2}+c_{j}^{2}\right)^{-\frac{1}{2}}$ and $F_{k j}=\left(g+\frac{\sin \left(c_{k} \cdot g\right)}{c_{k}}\right) \cdot\left(g+\frac{\sin \left(c_{j} \cdot g\right)}{c_{j}}\right)$.

The solution of Equation (4) named $Z_{k j}(z)$ can be written as follows:

$$
Z_{k j, u}(z)=A_{k j, u} \cdot \operatorname{ch}\left(\frac{z}{L_{k j}}\right)+B_{k j, u}\left(\frac{z}{L_{k j}}\right)-\frac{16 \cdot L_{k j}^{2} \cdot \sin \left(\frac{g \cdot c_{k}}{2}\right) \cdot \sin \left(\frac{g \cdot c_{j}}{2}\right)}{D \cdot c_{k} \cdot c_{j} \cdot F_{k j}} \cdot G_{u}(z) .
$$

The constants $A_{k j, u}$ and $B_{k j, u}$ in Equation (5) were determined using the boundary conditions at two interfaces [14]; one interface at (a) the $\mathrm{N}^{+}-\mathrm{P}$ boundary $z=0$ [14]:

$$
\left.D \cdot \frac{\partial \delta_{u}(x, y, z)}{\partial z}\right|_{z=0}=S f_{u} \cdot \delta_{u}(x, y, z=0)
$$

and (b) at the back side of the bifacial solar cell, $z=H$ [2] [14]:

$$
\left.D \cdot \frac{\partial Z_{k j}(z)}{\partial z}\right|_{z=H}=-S b_{u} \cdot Z_{k j, u}(H) \text {. }
$$

Using boundary conditions at the contact of two grains respectively in the $x$-direction at $x= \pm g / 2$, and $y$ direction at $y= \pm g / 2$, transcendal Equations (8) and (9) are obtained:

$$
\tan \left(c_{k} \cdot g / 2\right)=\frac{S g b}{c_{k} \cdot D}
$$

and

$$
\tan \left(c_{j} \cdot g / 2\right)=\frac{S g b}{c_{j} \cdot D}
$$

\subsection{Photocurrent Density}

The photocurrent density can be calculated by the following equation [2] [6]:

$$
I\left(S g b, g, \lambda, S f_{u}, S b_{u}\right)=\left.q \cdot D \cdot \frac{\partial \delta_{u}\left(z, S g b, g, \lambda, S f_{u}, S b_{u}\right)}{\partial z}\right|_{z=0} .
$$




\subsection{Photo Voltage}

Using the Boltzmann's relation, the photo voltage $V_{p h}$ can be expressed as [2] [6]:

$$
V_{p h}\left(S g b, g, \lambda, S f_{u}, S b_{u}\right)=V_{T} \cdot \operatorname{Ln}\left(\frac{\delta_{u}\left(z=0, S g b, g, \lambda, S f_{u}, S b_{u}\right)}{m_{0}}+1\right) .
$$

Here, $V_{T}$ is the thermal voltage, $m_{0}=\frac{n_{i}^{2}}{N b}$ with $N b$ the base doping density and $n_{i}$ the intrinsic carriers density.

\subsection{Solar Cell's Electric Power}

The power generated by the cell is given by [6]:

$$
P\left(S g b, g, \lambda, S f_{u}, S b_{u}\right)=V_{p h}\left(S g b, g, \lambda, S f_{u}, S b_{u}\right) \cdot I_{p h}\left(S g b, g, \lambda, S f_{u}, S b_{u}\right) .
$$

The solar cell's generated power depends on $S f_{u}$ and then is function of the solar cell's real operating point varying from the short-circuit operating point to the open one.

\section{Results and Discussions}

In Figures 2-5 we show curves of solar cell's electric power versus junction recombination velocity which varies from $10^{0}$ to $10^{12} \mathrm{~cm} / \mathrm{s}$ when the grain recombination velocity $(\mathrm{Sg} b)$, the grain size $(g)$, the wavelength $(\lambda)$ and the illumination mode varies, respectively. In Figures 2-5, the solar cell is illuminated by its front side.

We noted in each plot, as already shown by [5] in 1D study, that solar cell's power tends to zero, when $S f_{u}<$ $10^{2} \mathrm{~m} / \mathrm{s}$ and $S f_{u}>10^{10} \mathrm{~m} / \mathrm{s}$ corresponding to the open-circuit operating and short-circuit operating points, respectively. The open circuit operating point is characterized by the open circuit photovoltage $V_{o c}$ and where the photocurrent is null. The short-circuit operating point is characterised by the short-circuit photocurrent $I_{s c}$. In our previous studies [15], we remarked that poly crystalline solar cells tend to produce high open circuit photo voltage $\left(V_{o c}\right)$ and short-circuit photocurrent $\left(I_{s c}\right)$ as the grain size $(g)$ increases, conversely, $V_{o c}$ and $I_{s c}$ decrease with the increase of grain boundary recombination velocity $(S g b)[15]$.

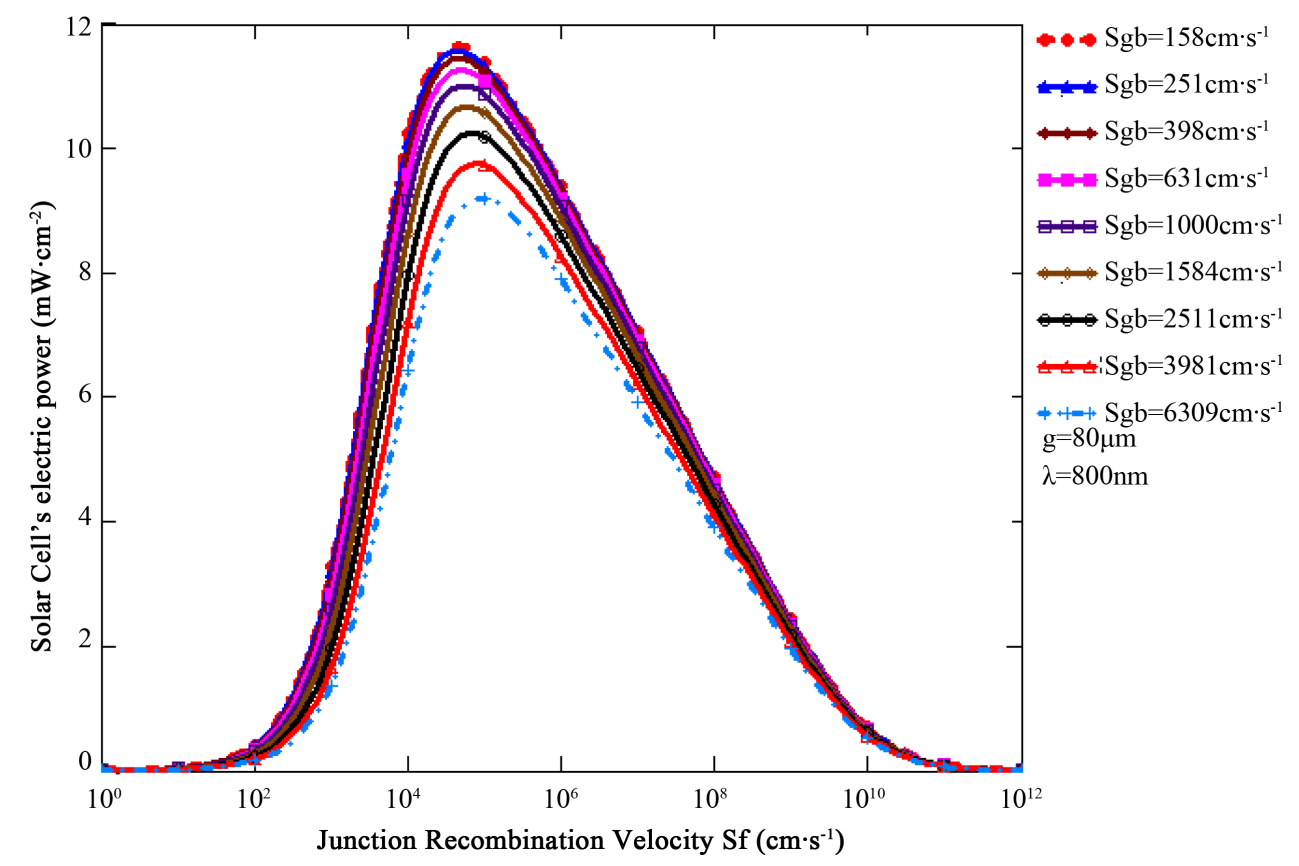

Figure 2. Solar cell's electric power versus junction recombination velocity for various grain boundary recombination velocity: $H=130 \mu \mathrm{m}$ and $D=26 \mathrm{~cm}^{2} \cdot \mathrm{s}^{-1}$. 


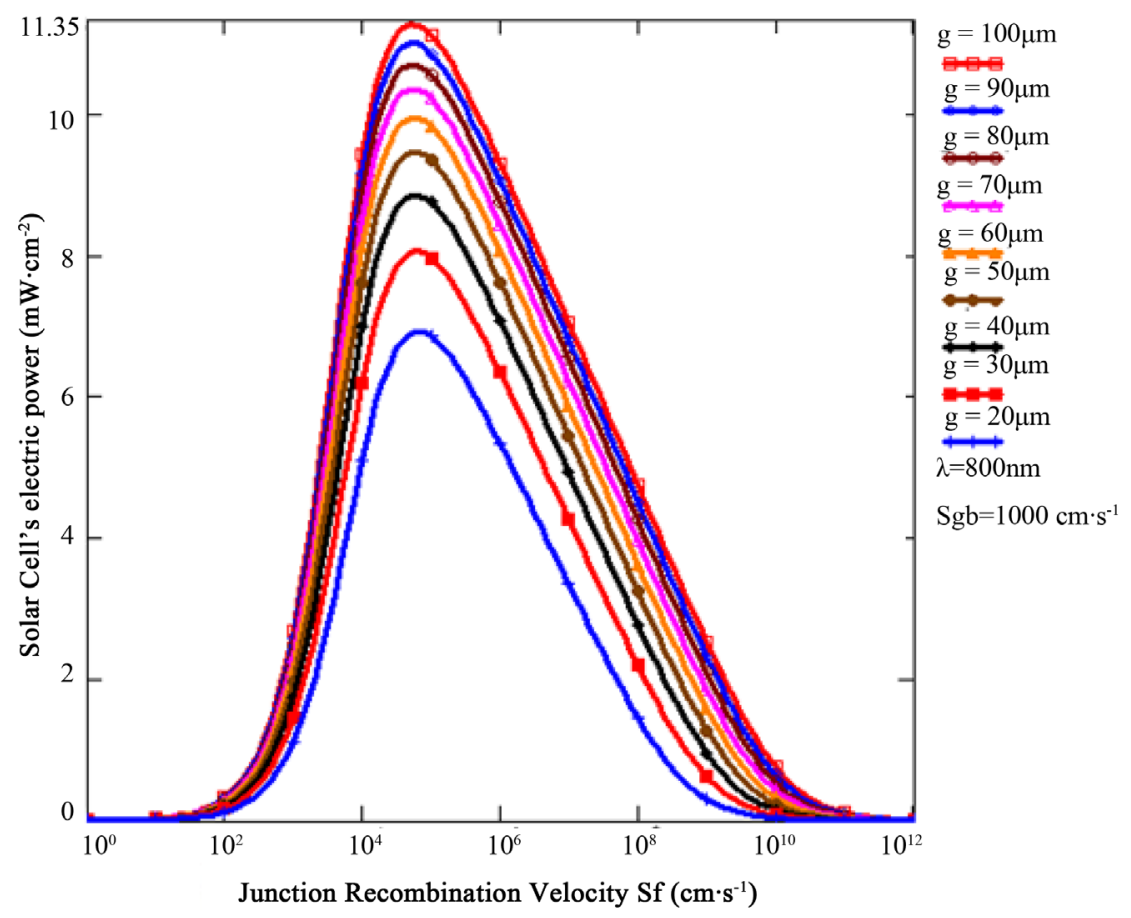

Figure 3. Solar cell's electric power versus junction recombination velocity for various grain size $(g): H=130 \mu \mathrm{m}$ and $D=26 \mathrm{~cm}^{2} \cdot \mathrm{s}^{-1}$.

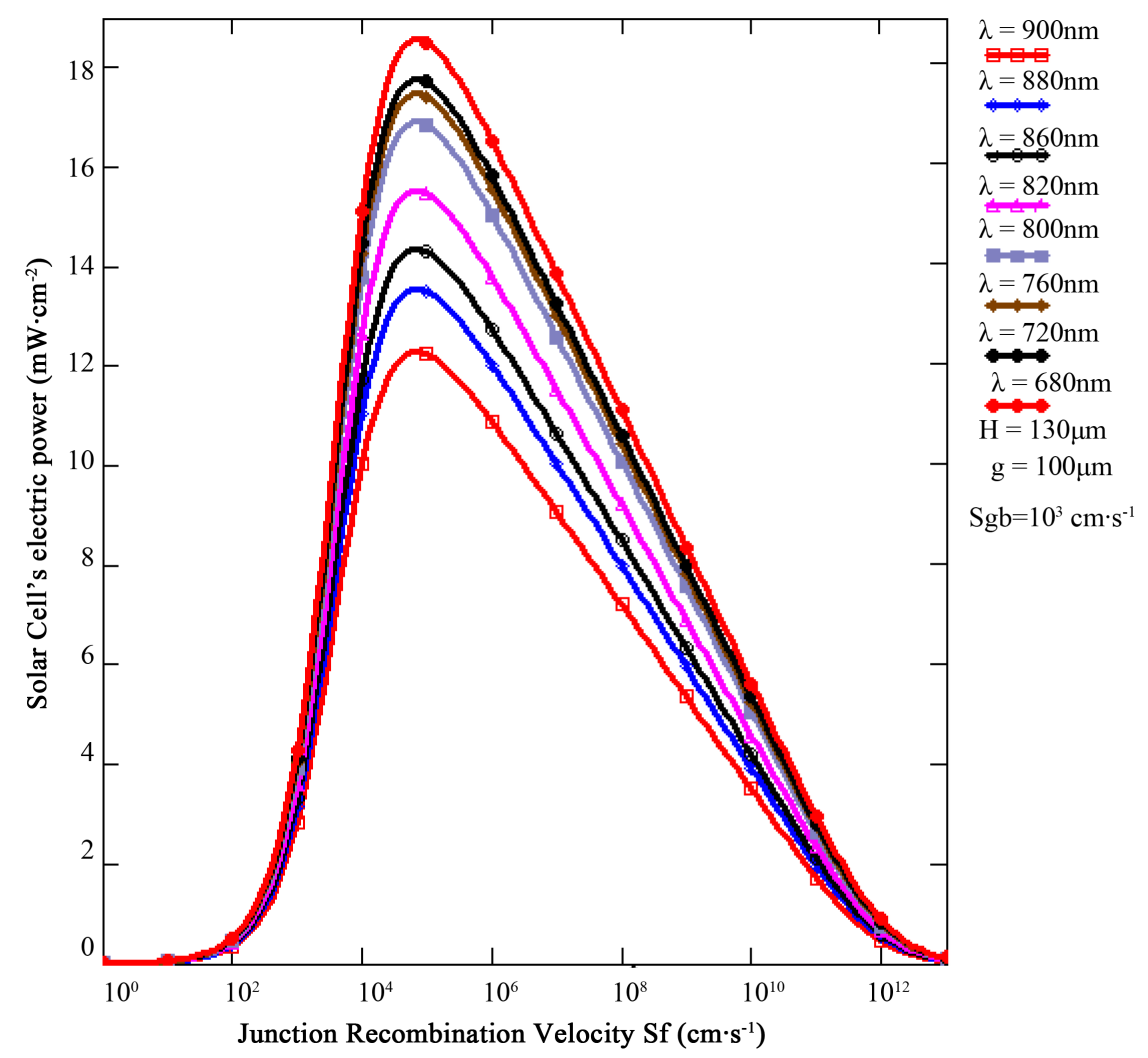

Figure 4. Solar cell's electric power versus junction recombination velocity for different incident light wavelength $(\lambda): H=130 \mu \mathrm{m}$ and $D=26 \mathrm{~cm}^{2} \cdot \mathrm{s}^{-1}$. 


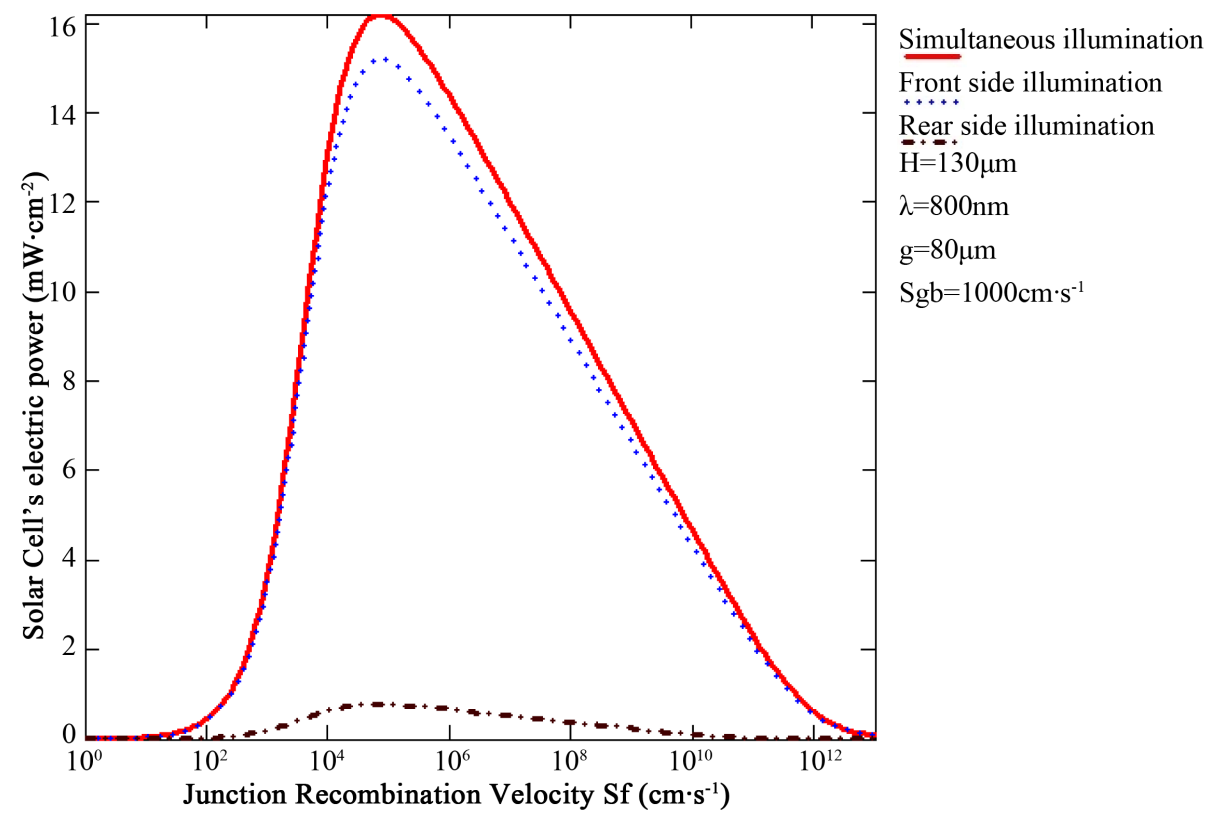

Figure 5. Solar cell's electric power versus junction recombination velocity $(u=f r, r, s)$.

We also remarked that the solar cell's electric power increases as the junction recombination velocity is high and goes through a maximum, named maximum power point, $P_{m}$. There is, for each $P_{m}$, a related junction recombination velocity $S f_{u, m}$ corresponding to the real operating point of the solar cell.

$P_{m}$ which is equal to the product of maximum power point photocurrent $\left(I_{m}\right)$ and photo voltage $\left(V_{m}\right)$, corresponds to the "knee" of the I-V curve [15] and is an optimum operating point such that solar cell delivers the maximum possible power to the external load. It is well known that, the maximum power point changes with atmospheric conditions and is usually determined by using the maximal power point tracking (MPPT) control technic as shown by [8]-[10].

Figure 2 and Figure 3 show respectively that the solar cell's maximum electric power $P_{m}$, increases for high values of grain size $(g)$ and decreases for high values of grain boundary recombination velocity $(S g b)$. It means that, increasing the grain size leads to fewer recombination in the bulk of the solar cell and hence high electrons' flow rate crossing the junction, corresponding to an increase of the photocurrent and the efficiency of the solar cell as it can be seen in [7]. The increasing of grain boundary recombination velocity (Sgb) give high recombination in the bulk of the solar cell and low efficiency [12] [15].

We also noted, for all plots, that the solar cell's electric power decreases from the junction recombination velocity $\left(S f_{u, m}\right)$ corresponding to the solar cell's maximum electric power $\left(P_{m}\right)$.

The effects of grain size $(g)$ and grain boundary recombination velocity $(S g b)$ upon the junction recombination velocity $\left(S f_{u, m}\right)$ corresponding to the solar cell's maximum electricpower $\left(P_{m}\right)$ is shown in Figure 2 and Figure 3. The low values of $S f_{u, m}$ are obtained with high grain size $(g)$ and low grain boundary recombination velocity $(S g b)$, respectively.

We deduced that, the increase of the grain size $(g)$ leads to the decrease of the grain boundary recombination velocity $(S g b)$. We can also conclude that, junction recombination velocity is, effectively, the sum of two terms as applied and demonstrated in some works [4] [5]:

- $S f_{0, u}$, the intrinsic junction recombination velocity imposed by the shunt resistance [4] [5];

- $S f_{j}$ which is related to current flow passed through the junction is imposed by the external load [4] [5].

For a fixed external load, corresponding to a specific value of $S f_{j}, S f_{0, u}$ increases with the grain boundary recombination $(S g b)$. This leads to the lower shunt resistance $\left(R_{s h}\right)$ and to the initiating short-circuit condition quickly reached [16]. For the same conditions, when the grain size $(g)$ increases, $S f_{0, u}$ and the shunt resistance decreases and increases, respectively. This situation corresponds to less recombination and the real operating point of the solar cell roll away of the initiating operating short-circuit condition studied in [16].

Evolution of the solar cell's electric power in relation to the junction recombination velocity when the wave- 
length is ranging from $680 \mathrm{~nm}$ to $900 \mathrm{~nm}$, corresponding at the domain of high wavelength is plotted on Figure 4. The solar cell is illuminated on its front side.

It is shown, in Figure 4, that the solar cell's electric power, for any operating point, decreases with the increase of wavelength $(\lambda)$ corresponding to low internal quantum efficiency (IQE) and small diffusion lengths of the solar cell [17]. Effect of this range of wavelength is explained using the thickness of emitter-base junction determination in a bifacial polycrystalline solar cell under real operating condition technic developed by [7]. This work [7] shows that the extension region's width in open circuit increases with wavelength due to the energy of the incoming photons. Hence, excess minority carriers and photocurrent density would decrease for high wavelength. Because, at high wavelength, corresponding to low energy, absorbed photons are low and then the maximum solar cell's electric power and efficiency would decrease as shown in [10].

Effect of the illumination mode on the solar cell's electric power is plotted in Figure 5. The $\mathrm{n}^{+}-\mathrm{p}-\mathrm{p}^{+}$bifacial solar cell has the advantage of receiving a light by its rear side. The bifacial solar cell thus receives a simultaneous illumination due the albedo [18]-[20]. As expected and demonstrated in [7] [14] the simultaneous illumination mode gives the highest solar cell's electric power. It is followed by the solar cell's electric power obtained by the front side illumination mode. These two solar cell's electric powers tend to merge when $S f_{u}<10^{4} \mathrm{~m} / \mathrm{s}$. The back side illumination mode's contribution can be neglected when compared to solar cell's electric power that are obtained by front side and both front and back sides. This is consistent with results found by [21] who studies a I-V characteristics curve for bifacial silicon solar cell under magnetic field. Authors demonstrated that best solar cell efficiency is obtained with both front and back sides illumination mode.

\section{Conclusions}

Using the junction recombination velocity concept permits us to determine solar cell's electric power for any operating point of the solar cell contrarily to others studies which used the maximal power point tracking (MPPT) control technic characterized by one operating point corresponding to the maximum output power delivered by solar cell.

It is shown that, for any real operating point, the solar cell's electric power increases with grain size $(g)$ corresponding then to the best solar cell. It decreases with high gain boundary recombination velocity $(S g b)$ and with high wavelength $(\lambda)$.

We noted that using an $\mathrm{n}^{+}-\mathrm{p}-\mathrm{p}^{+}$solar cell which could be illuminated by both front and back sides of the solar cell simultaneously had the advantage of giving a high electric power.

\section{References}

[1] Sissoko, G., Museruka, C., Correa, A., Gaye, I. and Ndiaye, A.L. (1996) Light Spectral Effect on Recombination Parameters of Silicon Solar Cell. Proceedings of World Renewable Energy Congress.

[2] Dugas, J. (1994) 3D Modelling of a Reverse Cell Made with Improved Multicrystalline Silicon Wafer. Solar Energy Materials \& Solar Cells, 32, 71-88. http://dx.doi.org/10.1016/0927-0248(94)90257-7

[3] Barro, F.I., Mbodji, S., Ndiaye, M., Maiga, A.S. and Sissoko, G. (2008) Bulk and Surface Recombination Parameters Measurement of Silicon Solar Cell under Constant White Bias Light. Journal des Sciences, 8, 37-41.

[4] Nzonzolo, Lilonga-Boyenga, D. and Sissoko, G. (2014) Illumination Level Effects on Macroscopic Parameters of a Bifacial Solar Cell. Energy and Power Engineering, 6, 25-36. http://dx.doi.org/10.4236/epe.2014.63004

[5] Zerbo, I., Zoungrana, M., Ouedraogo, A., Korgo, B., Zouma, B. and Bathiebo, D.J. (2014) Influence of Electromagnetic Waves Produced by an Amplitude Modulation Radio Antenna on the Electric Power Delivered by a Silicon Solar Cell. Global Journal of Pure and Applied Sciences, 20, 139-148. http://dx.doi.org/10.4314/gjpas.v20i2.9

[6] Madougou, S., Kaka, M. and Sissoko, G. (2010) Silicon Solar Cells: Recombination and Electrical Parameters. In: Rugescu, R.D., Ed., Solar Energy, InTech, Croatia.

[7] Mbodji, S., Mbow, B., Barro, F.I. and Sissoko, G. (2011) A 3D Model for Thickness and Diffusion Capacitance of Emitter-Base Junction Determination in a Bifacial Polycrystalline Solar Cell under Real Operating Condition. Turkish Journal of Physics, 15, 281-291.

[8] Skoplaki, E. and Palyvos, J.A. (2009) On the Temperature Dependence of Photovoltaic Module Electrical Performance: A Review of Efficiency/Power Correlations. Solar Energy, 83, 614-624. http://dx.doi.org/10.1016/j.solener.2008.10.008

[9] Hamrouni, N., Jraidi, M. and Chérif, A. (2008) Solar Radiation and Ambient Temperature Effects on the Performances 
of a PV Pumping System. Revue des Energies Renouvelables, 11, 95-106.

[10] Dinçer, F. and Meral, M.E. (2010) Critical Factors That Affecting Efficiency of Solar Cells. Journal of Smart Grid and Renewable Energy, 1, 47-50. http://dx.doi.org/10.4236/sgre.2010.11007

[11] Ndoye, S., Ndiaye, M., Diao, A., Dione, M.M., Diarisso, D., Bama, A.O.N., Ly, I., Sow, G., Maiga, A.S., Foulani, A., Barro, F.I. and Sissoko, G. (2010) Modeling and Simuling the Powering System of a Base Transmitter Station with a Standalone Photovoltaic Generator. Proceedings of 25th European Photovoltaic Solar Energy Conference and Exhibition, 5208-5211.

[12] Sissoko, G., Correa, A., Nanema, E., Diarra, M.N., Ndiaye, A.L. and Adj, M. (1998) Recombination Parameters Determination in a Double Sided Back-Surface Field Silicon Solar Cell. Proceedings of the World Rrenewable Energy Congress, 3, 1856-1859.

[13] Green, M.A. and Keevers, M. (1995) Optical Properties of Intrinsic Silicon at 300K. Progress in Photovoltaics, 3, 189192. http://dx.doi.org/10.1002/pip.4670030303

[14] Diallo, H.L., Maiga, A.S., Wereme, A. and Sissoko, G. (2008) New Approach of both Junction and Back Surface Recombination Velocities in a 3D Modelling Study of a Polycrystalline Silicon Solar Cell. The European Physical Journal Applied Physics, 42, 193-211. http://dx.doi.org/10.1051/epjap:2008085

[15] Mbodji, S., Ly, I., Diallo, H.L., Dione, M.M., Diasse, O. and Sissoko, G. (2012) Modeling Study of N ${ }^{+} / \mathrm{P}$ Solar Cell Resistances from Single I-V Characteristic Curve Considering the Junction Recombination Velocity (Sf). Research Journal of Applied Sciences, Engineering and Technology, 4, 1-7.

[16] Ly, I., Ndiaye, M., Wade, M., Thiam, N., Gueye, S. and Sissoko, G. (2013) Concept of Recombination Velocity Sfcc at the Junction of a Bifacial Silicon Solar Cell, in Steady State, Initiating the Short-Circuit Condition. Research Journal of Applied Sciences, Engineering and Technology, 5, 203-208.

[17] Madougou, S., Made, F., Boukary, M.S. and Sissoko, G. (2007) Recombination Parameters Determination by Using Internal Quantum Efficiency Data of Bifacial Silicon Solar Cells. Advanced Materials Research, 18-19, 313-324. http://dx.doi.org/10.4028/www.scientific.net/AMR.18-19.313

[18] Cuevas, A., Luque, A., Eguren, J. and Del Alamo, J. (1982) 50 Per Cent More Output Power from an Albedo Collecting Flat Panel Using Bifacial Solar Cells. Solar Energy, 29, 419-420. http://dx.doi.org/10.1016/0038-092X(82)90078-0

[19] Gophen, M. (2008) Land-Use, Albedo and Air Temperature Changes in the Hula Valley (Israel) during 1946-2008. Open Journal of Modern Hydrology, 4, 101-111. http://dx.doi.org/10.4236/ojmh.2014.44010

[20] Bird, R.E. and Riordan, C. (1985) Simple Solar Spectral Model for Direct and Diffuse Irradiance on Horizontal and Tilted Planes at the Earth's Surface for Cloudless Atmospheres. Journal of Climate and Applied Meteorology, 25, 8797. http://dx.doi.org/10.1175/1520-0450(1986)025<0087:SSSMFD>2.0.CO;2

[21] Madougou, S., Made, F., Boukary, M.S. and Sissoko, G. (2007) I-V Characteristics for Bifacial Silicon Solar Cell Studied under a Magnetic Field. Advanced Materials Research, 18-19, 303-312. http://dx.doi.org/10.4028/www.scientific.net/AMR.18-19.303 